\title{
A New Case of Purine Nucleoside Phosphorylase Deficiency: Enzymologic, Clinical, and Immunologic Characteristics
}

\author{
GERT RIJKSEN, WIETSE KUIS, SYBE K. WADMAN, LEO J. M. SPAAPEN, MARINUS DURAN,
} B. S. VOORBROOD, GERARD E. J. STAAL, JAN W. STOOP, AND BEN J. M. ZEGERS

Department of Haematology, Division of Medical Enzymology [G.R., G.E.J.S.], University Hospital and University: Hospital for Children and Youth "Het Wilhelmina Kinderziekenhuis," Utrecht, The Netherlands [W.K., S.K.W., L.J.M.S., M.D., B.J.M.Z.] and Juliana Ziekenhuis Department of Pediatrics, Rhenen, The Netherlands [B.S.V.]

\begin{abstract}
Deficiency of purine nucleoside phosphorylase (PNP) was detected in a 3-yr-old boy who was admitted for investigation of a behavior disorder and spastic diplegia. The urinary excretion of purines, analyzed by high-performance liquid chromatography, showed the presence of large amounts of (deoxy)inosine and (deoxy)guanosine and low uric acid levels. Analysis of the (deoxy)nucleotide pools of erythrocytes showed elevated levels of deoxyguanine nucleotides and NAD and decreased guanine nucleotides. PNP activity in red blood cells was $0.1-0.5 \%$ of normal on two occasions and undetectable on four later measurements. Furthermore no immunoreactive material could be detected in his red cell lysate using an anti-PNP antiserum. PNP activities in the red cells of the patient's parents were 35 and $50 \%$ of normal. The presence of (minor) residual PNP activity in the patient enabled the investigation of some enzyme properties after partial purification. No abnormalities could be detected in substrate affinity for inosine, heat stability, and electrophoretic properties. In the heterozygous parents no signs of a mutant enzyme could be found. The molecular specific activities of the parental enzymes were also normal, indicating that no immunoreactive material attributable to inactive-mutant enzyme subunits was present. A striking feature of the patient is the prevailing neurologic abnormalities presumably caused by the metabolic disorder. A severe lymphopenia exists; however, clinical symptoms of an immune deficiency did not become apparent until the age of $4 \mathrm{yr}$. (Pediatr Res 21: 137-141, 1987)
\end{abstract}

\section{Abbreviations}

PNP, purine nucleoside phosphorylase

dGTP, deoxyguanosine triphosphate

GTP, guanosine triphosphate

HGPRT, hypoxanthine guanine phosphoribosyl transferase

CSF, cerebrospinal fluid

ADA, adenosine deaminase

APRT, adenine phosphoribosyltransferase

AK, adenosine kinase

Received April 1, 1986; accepted September 17, 1986.

Reprint requests: Dr. B. J. M. Zegers, University Hospital for Children and Youth "Het Wilhelmina Kinderziekenhuis," P. O. box 18009, 3501 CA Utrecht, The Netherlands.
SAH, S-adenosyl homocysteine hydrolase dGDP, deoxyguanosine diphosphate

Since the first description of PNP deficiency associated with cellular immunodeficiency (1), about 20 patients from more than 10 families have been described (2-5). Clinically, PNP deficiency may manifest itself later in life than ADA deficiency, which affects cellular immune function and also humoral immunity. PNP deficient patients show an extreme susceptibility to viral infections such as varicella, measles, and cytomegalovirus. In addition neurologic abnormalities such as spastic tetraparesis often are part of the clinical syndrome $(4,5)$. T lymphocyte function is impaired in vivo and in vitro, whereas B lymphocyte function, as determined by the synthesis of specific antibodies, is usually intact in these patients. They excrete markedly increased quantities of inosine, deoxyinosine, guanosine, and deoxyguanosine and have elevated plasma levels of these metabolites. Urinary and plasma uric acid are markedly decreased. In addition, the erythrocytes contain relatively high levels of dGTP. The pathophysiologic mechanism that most researchers accept is dGTP-mediated inhibition of ribonucleotide reductase which leads to interference with DNA synthesis (6). An essential part of this hypothesis is the fact that cells of the lymphoid system, and in particular of the thymus, have high activities of the enzyme deoxycytidine kinase that converts deoxyguanosine to dGTP (7). However, the proposed mechanism does not fully explain the particular features of the immunodeficiency, nor does it explain the neurologic abnormalities of these patients.

The PNP gene locus is located on chromosome 14. The enzyme consists of three subunits, the trimer having a molecular weight of $84 \mathrm{kD}(6)$. In only a few patients a mutant PNP enzyme has been characterized directly $(8-11)$. The results showed the presence of kinetic abnormalities (10-12) and/or abnormal electrophoretic mobilities $(8,11)$ or altered heat stabilities $(9,11$, 12). In one family the presence of mutant PNP subunits in the parents of an immunodeficient patient could be shown directly by two-dimensional electrophoresis and peptide mapping of the purified enzyme $(13,14)$. The latter finding suggests that the PNP trimer in heterozygotes is composed of normal and variant subunits.

In this paper, we describe a new patient with PNP deficiency. This 3-yr-old boy was ascertained by urinary metabolite screening because of neurologic abnormalities. The presence of residual 
PNP activity in the erythrocytes of approximately $0.5 \%$ of normal enabled the characterization of some properties of the enzyme.

\section{CASE REPORT AND IMMUNOLOGICAL FINDINGS}

The patient, a boy, was born on April 6, 1981, after an uneventful pregnancy as the first child of healthy, apparently unrelated parents. At 2 yr a behavior disorder was observed, and a spastic diplegia was diagnosed. At 3 yr he was admitted to our hospital for metabolic screening, at which time the abnormalities commonly observed in PNP deficiency were found. This diagnosis was confirmed by enzyme assay (see "Results").

Apart from recurrent minor upper respiratory tract infections, no clinical indications of a cellular immunodeficiency existed at this time. The behavior disorder consisted of hyperactivity, a low tolerance for frustration, and excessive clinging to the mother. These problems were at least partly due to periods of hospitalization but reinforcement by cognitive deficiencies may have played a role. He was immunized with diphtheria toxoid, pertussis, tetanus toxoid, and polio myelitis virus at $3,4,5$, and 11 months and at 11 months with live attenuated measles vaccine. Laboratory investigation showed a profound lymphopenia (Table 1).

In vitro $\mathrm{T}$ cell function, as measured by the proliferative response of lymphocytes to mitogens, was slightly decreased compared with those of age-matched control donors. The response of the lymphocytes to the anamnestic antigen tetanus toxoid was positive. Serum immunoglobulin levels were normal for age, and on booster immunization the patient showed a significant rise in tetanus antibodies. However, immunization with the primary antigen helix pomatia hemocyanin did not lead to a significant antibody response. When the diagnosis was established, the patient received antibiotic prophylaxis with cotrimoxazole.

In 2-yr follow-up, the respiratory tract infections recurred, and on two occasions rhinovirus and parainfluenza type 2 and type 4 viruses were isolated. The spastic diplegia and behavior disorder did not worsen. Marked lymphopenia persisted. T lymphocyte subset percentages decreased, whereas B cells remained present in a normal percentage. The proliferative response of his lymphocytes to mitogens gradually decreased and the response to tetanus toxoid became negative. A lymph node biopsy showed a marked depletion of $\mathrm{T}$ lymphocytes, whereas the normally de-

Table 1. Immune function of propositus

\begin{tabular}{|c|c|c|c|}
\hline & $\begin{array}{l}\text { Initial } \\
\text { results } \\
(3 \mathrm{yr})\end{array}$ & $\begin{array}{l}\text { Follow-up } \\
(3.5-5 \mathrm{yr})\end{array}$ & $\begin{array}{l}\text { Age- } \\
\text { matched } \\
\text { controls }\end{array}$ \\
\hline Lymphocytes $\left(\mathrm{mm}^{3}\right)$ & $<500$ & $100-200$ & $>2000$ \\
\hline$\%$ T cells $\left(\mathrm{OKT}^{+}\right)^{*}$ & $40-55$ & $20-40$ & $50-80$ \\
\hline$\% \mathrm{~T}$ inducer cells $\left(\mathrm{OKT}^{+}\right)$ & $20-50$ & $6-20$ & $40-65$ \\
\hline$\% \mathrm{~T}$ sup/cyt cells $\left(\mathrm{OKT} 8^{+}\right)$ & $10-16$ & $5-10$ & $15-25$ \\
\hline$\%$ B cells & $10-19$ & $7.5-11$ & $5-16$ \\
\hline \multicolumn{4}{|l|}{$\begin{array}{l}\% \text { In vitro proliferative re- } \\
\text { sponse } †\end{array}$} \\
\hline Phytohemagglutinin & $80-100$ & $10-40$ & $100 \pm 30$ \\
\hline Concanavalin A & $50-80$ & $10-40$ & $100 \pm 30$ \\
\hline Pokeweed mitogen & $50-100$ & $30-50$ & $100 \pm 30$ \\
\hline Tetanus toxoid & Positive & Negative & Positive \\
\hline Allogeneic cells & Normal & ND $\ddagger$ & Positive \\
\hline \multicolumn{4}{|l|}{ Serum } \\
\hline IgM (g/liter) & 1.6 & $1.4-1.6$ & $1.0 \pm 0.37$ \\
\hline $\mathrm{IgG}$ & 6.1 & $5.4-6.3$ & $8.9 \pm 1.8$ \\
\hline $\operatorname{IgA}$ & 1.1 & $0.7-1.9$ & $0.85 \pm 0.37$ \\
\hline
\end{tabular}

* Per 100 lymphocytes

$\uparrow$ Thymidine uptake of age matched control donors.

$\ddagger$ Not done. veloped germinal centers contained IgM and IgD bearing $B$ lymphocytes; plasma cells were not present. In the bone marrow: pre-B cells, IgM, IgD, and IgG bearing B cells and plasma cells were present.

\section{MATERIALS AND METHODS}

Analysis of urinary purines and erythrocyte (deoxy)ribonucleotides. Screening for urinary purine bases and nucleosides was performed by automated column liquid chromatography using a slightly modified Technicon TSM 1 amino acid analyzer (15, 16). The quantitative determination of (deoxy)inosine and (deoxy)guanosine in urine, plasma, and cerebrospinal fluid was achieved with a high-performance liquid chromatographic technique (17), in which the deoxynucleosides remain intact. Plasma uric acid was analyzed by the uricase method. (Deoxy)ribonucleotides were released from erythrocytes by treatment of the patient's whole blood with perchloric acid immediately after collection. These compounds were analyzed by highperformance liquid chromatography essentially as described previously (17). dGTP concentrations were measured after the removal of GTP by periodate oxidation (17).

Enzyme assays. Venous blood from patient, parents, and controls was collected in heparin $(30 \mathrm{U} / \mathrm{ml})$ and centrifuged at $1000 \times g$ for $10 \mathrm{~min}$. Red cells were washed twice with physiologic saline and stored at $-70^{\circ} \mathrm{C}$ until analysis. Hemolysates were prepared by adding an appropriate volume of $0.01 \mathrm{M}$ Tris$\mathrm{HCl}(\mathrm{pH} 7.4)$.

PNP activities were determined spectrophotometrically in hemolysates by measuring the initial rate of the conversion of inosine according to the coupled xanthine oxidase method of Kalckar (18). Substrate concentrations were $25 \mu \mathrm{M}$ and $0.2 \mathrm{M}$ for inosine and $\mathrm{Na}_{2} \mathrm{HPO}_{4}$, respectively. Alternatively, PNP activity was measured by radiochemical methods: the conversion of inosine to hypoxanthine was measured by incubating $0.5-2 \mu \mathrm{g}$ lysate protein $\left(\sim 300 \mu \mathrm{g}\right.$ for patient) with $0.2 \mathrm{mM}{ }^{14} \mathrm{C}$-inosine in $0.125 \mathrm{M}$ Tris-HCl buffer (pH 7.4), $2.5 \mathrm{mM}$ EDTA, $1.25 \mathrm{mM} \mathrm{K}$ phosphate for $20 \mathrm{~min}$. The reverse reaction was measured by substitution of inosine and phosphate by $0.1 \mathrm{mM}{ }^{14} \mathrm{C}$-hypoxanthine and $1.25 \mathrm{mM}$ ribose-1-phosphate (pH 7.0). The enzymes ADA, HGPRT, APRT, AK, were assayed by established methods (19). SAH was measured according to Hershfield et al. (20). In all radiochemical assays substrate and reaction product(s) were separated by thin-layer chromatography on PEI-cellulose sheets (SEL 300 PEI, Macherey-Nagel, Düren, West Germany) with $0.15 \mathrm{M} \mathrm{NaCl}$ (PNP, HPRT, APRT, AK) or butanol/methanol/ $\mathrm{H}_{2} \mathrm{O} / \mathrm{NH}_{4} \mathrm{OH}, 60 / 20 / 20 / 1$ (v/v) (ADA, SAH) as the eluents.

Compounds were identified by cochromatography of unlabeled standards, which could be visualized under ultraviolet light. The fluorescent spots were cut out, and the radioactivity was quantitated in a liquid scintillation counter.

The enzyme activities were expressed as nanomoles substrate converted per min per mg protein. Protein was determined by the method of Lowry et al. (21) or approximated by the measurement of hemoglobin (hemolysates).

Partial purification of PNP. PNP of patient and controls was partial purified by batch-wise treatment of hemolysates with DEAE-Sephadex A-50 (Pharmacia, Uppsala, Sweden) and equilibrated in $10 \mathrm{mM} \mathrm{Na}, \mathrm{K}$-phosphate buffer ( $\mathrm{pH} \mathrm{7.0)}$. After washing with $50 \mathrm{mM}$ buffer, the enzyme was eluted with 100 $\mathrm{mM}$ Na,K-phosphate buffer ( $\mathrm{pH} 7.0)$ containing $5 \%\left(\mathrm{NH}_{4}\right)_{2} \mathrm{SO}_{4}$ and $10 \mathrm{mM}$ dithiothreitol and precipitated by adding $\left(\mathrm{NH}_{4}\right)_{2} \mathrm{SO}_{4}$ to a final concentration of $60 \%$. After standing overnight the precipitate was collected by centrifugation. The pellet was dissolved in $50 \mathrm{mM} \mathrm{Na}, \mathrm{K}$-phosphate buffer $(\mathrm{pH} \mathrm{7.0)}$ containing 10 $\mathrm{mM}$ dithiothreitol and dialyzed extensively against the same buffer.

Electrophoresis. Electrophoresis was performed at room temperature on cellulose acetate strips (Chemetron, Milan, Italy) using Tris-borate buffer ( $\mathrm{pH} 7.2 ; 0.1 \mathrm{M}$ boric acid, $0.004 \mathrm{M}$ Tris) 
as the electrode buffer. Electrophoresis was conducted for 30 $\mathrm{min}$ at $150 \mathrm{~V}$ followed by an additional $60 \mathrm{~min}$ at $260 \mathrm{~V}$. The PNP activity bands were specifically stained as described by Edwards et al. (22).

Immunoprecipitation. Determination of the molecular specific activities (defined as the amount of antiserum necessary to precipitate $1 \mathrm{U}$ of enzyme activity) was performed by incubating $10 \mathrm{mU}$ of PNP activity with a series of dilutions of rabbit antiPNP antiserum in a volume of $200 \mu \mathrm{l}$ at $37^{\circ} \mathrm{C}$ for $60 \mathrm{~min}$. After addition of $50 \mu \mathrm{l}$ of a $30 \%$ solution of polyethyleneglycol 6000 and incubation for another $15 \mathrm{~min}$ at $0^{\circ} \mathrm{C}$ the antigen-antibody complex was collected by centrifugation $(20 \mathrm{~min}, 48,000 \times \mathrm{g})$, and the remaining enzyme activity in the supernatant was measured spectrophotometrically. The rabbit anti-PNP antiserum was a kind gift of Dr. W. R. A. Osborne (Department of Pediatrics, University of Washington, Seattle, WA).

\section{RESULTS}

Analysis of urine, plasma, and CSF for purines. The screening procedures for inherited metabolic disorders showed a strikingly decreased urine uric acid/creatinine ratio of $0.5 \mathrm{mmol} / \mathrm{g}$ creatinine (age-matched controls 3-9 mmol/g creatinine). This hypouricosuria was associated with considerable levels of deoxyinosine and (deoxy)guanosine in urine, plasma, and CSF (Table 2). The total oxypurine excretion $(\sim 23 \mathrm{mmol} / \mathrm{g}$ creatinine) was higher than that observed in controls (3-9 $\mathrm{mmol} / \mathrm{g}$ creatinine). Both parents excreted normal amounts of uric acid (2.0 and 1.7 $\mathrm{mmol} / \mathrm{g}$ creatinine, respectively); (deoxy)nucleosides were not found in their urines (data not shown).

(Deoxy)nucleotide pools of erythrocytes. The patient's erythrocyte (deoxy)ribonucleotide content is shown in Table 3. Normal levels of adenine nucleotides were observed in all samples, except for a two-fold increase in the concentration of NAD, which was confirmed on several occasions. The concentrations of guanosine diphosphate and GTP were decreased, whereas the deoxyguanosine nucleotides were present in increased amounts.

Table 2. Uric acid and deoxynucleosides in urine, plasma, and CSF of propositus

\begin{tabular}{lccc}
\hline & $\begin{array}{c}\text { Urine } \\
(\mathrm{mmol} / \mathrm{g} \text { creatinine })\end{array}$ & $\begin{array}{c}\text { Plasma } \\
(\mu \mathrm{mol} / \mathrm{liter})\end{array}$ & $\begin{array}{c}\text { CSF } \\
(\mu \mathrm{mol} / \mathrm{liter})\end{array}$ \\
\hline Uric acid & 0.5 & $20^{*}$ & $10 \dagger$ \\
Inosine $\ddagger$ & 12.7 & 31 & 29 \\
Guanosine $\ddagger$ & 4.6 & 5 & 4 \\
Deoxyinosine $\ddagger$ & 3.7 & 2 & 2 \\
Deoxyguanosine $\neq$ & 2.5 & 2 & 1 \\
\hline
\end{tabular}

* Normal values $120-350 \mu \mathrm{mol} /$ liter.

$\uparrow$ Normal values $10-40 \mu \mathrm{mol} /$ liter.

$\$$ (Deoxy)guanosine and (deoxy)inosine are normally below the level of detection.

Table 3. Nucleotides and deoxynucleotides in erythrocytes of propositus

\begin{tabular}{lcc}
\hline & & $\begin{array}{c}\text { Controls } \\
(\mu \mathrm{mol} / \text { liter packed cells }) \\
(n=8)\end{array}$ \\
\hline ATP & Propositus & $1460 \pm 200$ \\
ADP & 1360 & $170 \pm 14$ \\
GTP & 193 & $69 \pm 14$ \\
dGTP & 14 & ND* $^{*}$ \\
GDP & 5 & $24 \pm 8$ \\
dGDP & Trace & ND* $^{*}$ \\
NAD & 282 & $112 \pm 27$ \\
NADP & 52 & $45 \pm 7$ \\
\hline
\end{tabular}
liter.
Red cell enzyme activities. In two of the patient's earlier blood samples the red cell PNP activity was $\sim 0.1-2 \%$ of normal (Table 4). However, on several later occasions no residual PNP activity could be detected, either radiochemically or spectrophotometrically. The detection limit of our radiochemical assay, using high amounts of hemolysate, was estimated to be $\sim 0.05 \%$ of control. Red cell SAH activity was decreased on two of four occasions, and APRT and AK activities were near the upper limits of normal. The parents' red cell PNP activities were in the heterozygous range $(\sim 30$ and $50 \%$ of normal) (Table 4$)$.

Enzyme properties. The presence of some residual PNP activity in one patient's blood samples prompted the partial purification of the enzyme from the patient. Subsequently, the substrate affinity (inosine), the electrophoretic properties, and the heat stability were studied and compared with the characteristics of partial purified enzyme of a control donor.

When varying the inosine concentrations, Lineweaver-Burke plots were produced, showing two intersecting straight lines due to the presence of multimolecular forms of the enzyme with different substrate affinities, which are generated during red cell ageing (22-24).

However, plots obtained from proband and control were similar (Fig. 1), and about the same $K_{\mathrm{m}}$ values are obtained when linear parts of the figures were extrapolated (Table 5). The kinetic behavior of the parental enzymes was normal as well.

The electrophoretic pattern of two partially purified PNP samples showed a multibanded pattern-due to the presence of multimolecular forms of the enzyme-without any differences in electrophoretic mobilities between patient and control. The electrophoresis of parental hemolysates showed a completely normal pattern as well (results not shown).

Table 4. Purine enzyme activities in hemolysates*

\begin{tabular}{llllcc}
\hline & \multicolumn{1}{c}{ Patient } & Father & Mother & Controls & $n$ \\
\hline PNPt & $0.5 \ddagger$ & 13.5 & 8.9 & $23.7 \pm 6.3$ & 30 \\
PNP, ino $\rightarrow$ hx & $0.03 \ddagger$ & 4.2 & 2.4 & $10.4 \pm 5.2$ & 30 \\
PNP, hx $\rightarrow$ ino & $0.04 \ddagger$ & 23.6 & 16.7 & $55 \pm 28$ & 30 \\
ADA & 1.22 & ND $\$$ & ND & $2.22 \pm 1.28$ & 30 \\
AK & 0.27 & ND & ND & $0.18 \pm 0.09$ & 30 \\
HPRT & 1.73 & ND & ND & $1.68 \pm 0.17$ & 30 \\
APRT & 0.42 & 0.18 & 0.17 & $0.28 \pm 0.08$ & 30 \\
SAH & $0.033 ; 0.027$ & 0.067 & 0.078 & $0.120 \pm 0.055$ & 9 \\
& $0.098 ; 0.101$ & & & & \\
\hline
\end{tabular}

*Values are means $\pm \mathrm{SD}$ expressed in $\mathrm{nmol} \cdot \mathrm{min}^{-1} \cdot \mathrm{mg}^{-1}$.

$\uparrow$ Spectrophotometric assay of PNP; all other enzymes were assayed radiochemically.

$¥$ On four later occasions PNP activity was below the detection limit of $0.05 \%$.

$\S$ Not done.

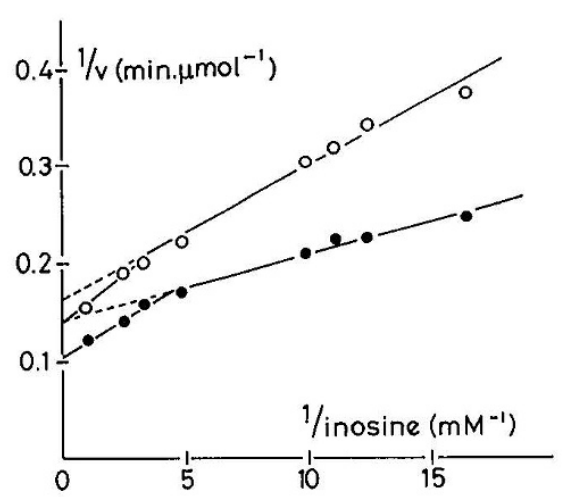

Fig. 1. Double reciprocal plot of PNP activity versus varying concentrations of inosine. Spectrophotometric assay of partial purified preparations from patient $(\mathrm{O})$ and control $(\bullet)$. 
Table 5. Apparent $K_{m}$ values for inosine of PNP from patient, parents, and controls

\begin{tabular}{cccc}
\hline & Sample & \multicolumn{2}{c}{$K_{\mathrm{m}}$ apparent inosine $(\mu \mathrm{M})$} \\
\cline { 3 - 4 } Subject & preparation & Inosine $<200 \mu \mathrm{M}$ & Inosine $>200 \mu \mathrm{M}$ \\
\hline Patient & $\begin{array}{c}\text { Partial pu- } \\
\text { rification }\end{array}$ & 50 & 143 \\
Control & $\begin{array}{c}\text { Partial pu- } \\
\text { rification }\end{array}$ & 74 & 131 \\
Father & $\begin{array}{c}\text { Hemolysate } \\
\text { Mother }\end{array}$ & 38 & 105 \\
Controls & Hemolysate & 50 & 122 \\
Hemolysate & $47 ; 50^{*}$ & $133 ; 165^{*}$ \\
\hline
\end{tabular}

* Values of two individual donors.

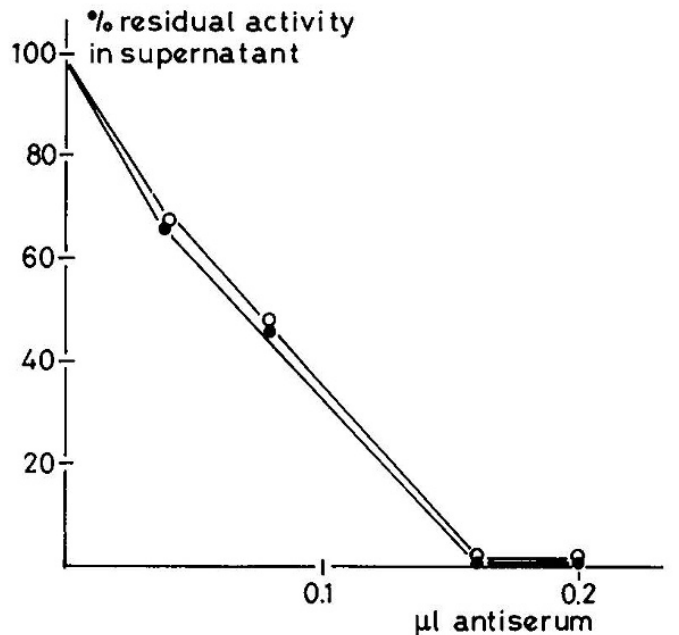

Fig. 2. Immunoprecipitation of PNP activity from a control hemolysate with $(O)$ or without $(\bullet)$ the addition of an identical amount of PNP deficient hemolysate.

Table 6. Molecular specific activity of PNP in hemolysates

\begin{tabular}{lc}
\hline & $\mu \mathrm{l}$ antiserum/U PNP \\
\hline Controls $(n=4)$ & $2.68 \pm 0.12(\mathrm{SD})$ \\
Father & 2.69 \\
Mother & 2.63 \\
\hline
\end{tabular}

The heat stability at $60^{\circ} \mathrm{C}$ of the partially purified sample from the patient and the hemolysates from the parents were completely normal.

Immunoprecipitation studies. The presence of immunoreactive material was investigated by immunoprecipitation with antiPNP antibodies. The amount of antiserum required to precipitate a fixed amount of PNP activity in a hemolysate of a normal control was not influenced by the addition of an identical amount of PNP deficient hemolysate (Fig. 2). The detection limit of this method was estimated to be about $5 \%$ of normal immunoreactive material, therefore the amount of immunoreactive material of the patient that is identifiable by the anti-PNP antibodies is less than $5 \%$.

The molecular specific activity (amount of antiserum necessary to precipitate $1 \mathrm{U}$ of enzyme activity) of PNP in the red cells of the obligate heterozygotes was completely normal (Table 6). This means that no immunoreactive material is present attributable to inactive-mutant-enzyme subunits, because their presence would have increased the consumption of antiserum per $U$ of enzyme activity.

\section{DISCUSSION}

On the basis of urinary analysis and erythrocyte enzyme determinations the diagnosis of PNP deficiency could be made in this patient. The urinary excretion profile of purines together with the red cell PNP activities are in accord with previous cases of PNP deficiency, i.e. increased urinary excretion of PNP substrates (deoxy)inosine and (deoxy)guanosine and diminished uric acid excretion $(6,25)$. The residual erythrocyte PNP activity of $0.5 \%$ or less is also similar to previously described cases. Fibroblasts and peripheral blood mononuclear cells showed negligible PNP enzyme activities.

Most if not all patients with PNP deficiency and without a positive family history present with infectious problems and severe lymphopenia. The time of onset of clinical symptoms may vary, but mostly occurs at the end of the first year or in the 2 nd yr of life (2). This relatively late onset of the clinical syndrome of a cellular immunodeficiency has been attributed to a gradual but progressive effect of the toxic metabolite deoxyguanosine on the function and development of $\mathrm{T}$ lymphocytes (4). The present case seems unusual in its clinical presentation since neurological symptoms predominate, and recurrent respiratory infections did not become apparent until age 4. From the time the patient came under our care, the in vitro $\mathrm{T}$ cell function gradually diminished (Table 1). However, compared with other PNP deficient patients $(2,4)$ the process of waning T cell function was rather slow. Since fibroblasts and lymphocytes are also severely deficient in PNP (see above), a differential cellular expression of the enzyme deficiency is not likely to exist. The total oxypurine excretion is about the same as found previously in three siblings of a PNP-deficient Dutch family (4), and this also holds true for deoxyguanosine, which is the toxic metabolite for the lymphoid system. Therefore there is no satisfactory explanation for the relatively late expression of an immune deficiency. Late onset of immune deficiency has been described in partial PNP deficiency occurring in two brothers with a mutant enzyme $(9,10)$.

In agreement with results of others $(6,26)$, analysis of intracellular (deoxy)nucleotide pools showed a pattern of increased dGTP, dGDP, and NAD with low levels of guanine nucleotides. Unfortunately, the real target of dGTP toxicity could not be investigated because of the lymphopenia. However, using normal peripheral blood lymphocytes treated with the PNP inhibitor 8$\mathrm{NH}_{2}$-guanosine, Spaapen et al. (27) showed that on activation with T-cell mitogens, and in the presence of deoxyguanosine, intracellular dGTP increases. The low erythrocyte GTP levels are compatible with the lack of formation of the purine bases hypoxanthine and guanine $(26,28)$. Consequently, these are unavailable for the HGPRT reaction, thus inducing a secondary functional deficiency of the enzyme. As a consequence phosphoribosylpyrophosphate is not used and accumulates (28) with a concomitant decrease of guanine nucleotides. In the synthetic pathway of NAD the reaction catalyzed by the enzyme nicotinamide phosphoribosyltransferase (EC 2.4.2.12) is favored by high concentrations of phosphoribosylpyrophosphate. This phenomenon might well underlie the present finding of a high NAD concentration (Table 3$)(26,28)$, which in turn contributes to the depletion of guanine nucleotides by inhibition of IMP dehydrogenase which converts IMP into GMP (29).

It is generally agreed that the neurological symptoms, i.e., tetra-or diparesis $(2,4$, and present study), that are associated with PNP deficiency are in some way causally related to the inborn error (5). In the present patient the possibility of persistent virus infection of the brain responsible for the neurological symptoms could only be investigated by viral cultures of CSF that were negative. Analysis of the CSF for (deoxy)nucleosides showed amounts that are almost equal to the plasma levels. This finding may indicate that no relative excessive production of (deoxy)nucleosides occurs locally in the brain. We previously 
discussed (4) that lack of the substrates for HGPRT (i.e., hypoxanthine and guanine) may be responsible for the neurological symptoms since it has been shown in rat brain tissue that the central nervous system strongly depends on the salvage pathway for purine synthesis (30). More recently, Simmonds et al. (31) when presenting the low erythrocyte GTP levels in a PNP deficient patient (see also Table 3) suggested that PNP deficient patients also suffer from a secondary functional HGPRT deficiency.

As stated in the introduction, the few PNP-deficient patients that could be studied for enzyme properties showed either kinetic abnormalities and/or electrophoretic abnormalities or abnormal heat stabilities. Studies using parental erythrocytes confirmed the presence of mutant enzymes in these families (11-13). In the present patient the residual red cell PNP enzyme appeared to be completely normal with respect to its kinetic properties, electrophoretic mobility, and heat stability. In the heterozygous parents no signs of the presence of a structural mutated PNP could be found either, neither by study of the enzyme properties nor by using an anti-PNP antibody. The latter seems at variance with previous studies of heterozygous individuals in which the presence of immunoreactive material attributable to inactive mutant subunits could be found $(32,33)$.

Acknowledgments. The authors acknowledge the expert technical assistance of P. K. de Bree, N. Loof, M. Streefkerk, and B. van Oirschot. Dr. W. Kleyer, Erasmus University, Rotterdam, performed the enzyme determinations in the fibroblasts. Drs. J. Huber and H. J. Schuurman, University Hospital, Utrecht, analyzed the lymph node biopsy. Dr. G. T. Rijkers, University Childrens Hospital, Utrecht, contributed to the discussion of results. E. L. Huisman-Backer Dirks is thanked for skillful secretarial help.

\section{REFERENCES}

1. Giblett ER, Ammann AJ, Wara DW, Sandman R, Diamond LK 1975 Nucleoside-phosphorylase deficiency in a child with severely defective T-cell immunity and normal B-cell immunity. Lancet 1:1010-1013

2. Ammann AJ 1979 Immunological aberrations in purine nucleoside phosphorylase deficiencies. In: Enzyme Defects and Immune Dysfunction. Ciba Foundation Symposium no. 68, pp 55-75

3. Zegers BJM. Stoop JW 1983 Therapy in adenosine deaminase and purine nucleoside phosphorylase deficient patients. Clin Biochem 16:43-47

4. Stoop JW, Zegers BJM. Hendrickx GFM. Siegenbeek van Heukelom LH. Staal GEJ, de Bree PK. Wadman SK. Ballieux RE 1977 Purine nucleoside phosphorylase deficiency associated with selective cellular immunodeficiency. N Engl J Med 296:651-655

5. Watson AR, Evans DJK. Marsden NB, Miller V, Rogers PA 1981 Purine nucleoside phosphorylase deficiency associated with a fatal lymphoproliferative disorder. Arch Dis Child 56:563-565

6. Martin DW. Gelfand WE 1981 Biochemistry of diseases of immunodevelopment. Ann Rev Biochem 50:845-877

7. Carson DA, Kaye J, Seegmiller JE 1977 Lymphospecific toxicity in adenosine deaminase deficiency and purine nucleoside phosphorylase deficiency: possible role of nucleoside kinase(s). Proc Natl Acad Sci USA 74:5677-5681

8. Osborne WRA. Chen SH, Giblett ER, Biggar WD, Ammann AA. Scott CR 1977 Purine nucleoside phosphorylase deficiency. Evidence for molecular heterogeneity in two families with enzyme-deficient members. J Clin Invest 60:741-746

9. Fox IH, Andres CM. Gelfand EW, Biggar D 1977 Purine nucleoside phosphorylase deficiency: altered kinetic properties of a mutant enzyme. Science 197:1084-1086

10. Wortmann RL. Andres C. Kaminska J, Mejias E. Gelfand E, Arnold W, Rich K. Fox IH 1979 Purine nucleoside phosphorylase deficiency. Biochemical properties and heterogeneity in two families. Arthritis Rheum 22:524-531
11. Fox IH, Andres CM, Kaminska J, Wortmann RL 1979 Purine nucleoside phosphorylase: the normal enzyme and structural alterations in immunodeficiency disease. In: Enzyme Defects and Immune Dysfunction. Ciba Foundation Symposium no 68, pp 193-202

12. Siegenbeek van Heukelom LH, Staal GEJ, Stoop JW, Zegers BJM 1976 An abnormal form of purine nucleoside phosphorylase in a family with a child with severe defective T-cell and normal B-cell immunity. Clin Chim Acta $72: 117-124$

13. Gudas LJ, Zannis VI. Clift SM, Ammann AJ, Staal GEJ, Martin DW 1978 Characterization of mutant subunits of human purine nucleoside phosphorylase. J Biol Chem 153:9816-9824

14. McRoberts JA, Martin DW 1980 Submolecular characterization of a mutant human purine-nucleoside phosphorylase. J Biol Chem 255:5605-5615

15. Wadman SK, de Bree PK, van Gennip AH, Stoop JW, Zegers BJM, Staal GEJ, Siegenbeek van Heukelom LH 1977 Urinary purines in a patient with severely defective $T$ cell immunity and a purine nucleoside phosphorylase deficiency, In: Müller MM, Kaiser E, Seegmiller JE, (eds) Purine Metabolism in Man, Vol II. Regulation of Pathways and Enzyme Defects. Plenum Press, New York. pp 471-476

16. de Bree PK, Wadman SK, Duran M, Fabery de Jonge H 1986 Diagnosis of inherited adenylosuccinase deficiency by thin layer chromatography of urinary imidazoles and by automated cation exchange column chromatography of purines. Clin Chim Acta 156:279-288

17. Spaapen LJM, Scharenberg JGM, Zegers BJM, Rijkers GT, Duran M, Wadman SK 1986 Intracellular purine and pyrimidine nucleotide pools of human T and B lymphocytes. In: Nyhan WL, Thompson LF, Watts RWE (eds) Purine and Pyrimidine Metabolism in Man, Vol V. Plenum Press, New York, pp 567-573

18. Kalckar HM 1947 Differential spectrophotometry of purine compounds by means of specific enzymes. J Biol Chem 167:429-443

19. Rijksen G, Staal GEJ, van der Vlist MJM, Beemer FA, Troost J, Gutensohn W, van Laarhoven JPRM, de Bruyn CHMM 1981 Partial hypoxanthineguanine phosphoribosyl transferase deficiency with full expression of the Lesch-Nyhan syndrome. Hum Genet 57:39-47

20. Hershfield MS 1979 Apparent suicide inactivation of human lymphoblast Sadenosylhomocysteine hydrolase by $2^{\prime}$-deoxyadenosine and adenine arabinoside: a basis for direct toxic effects of analogs of adenosine. J Biol Chem 254:22-24

21. Lowry OH, Rosebrough NJ, Farr AL, Randall RJ 195I Protein measurement with the Folin phenol reagent. J Biol Chem 193:265-275

22. Edwards YN, Hopkinson DA, Harris H 197! Inherited variants of human nucleoside phosphorylase. Ann Hum Genet (Lond) 34:395-408

23. Turner BM. Fisher RA, Harris H 1971 An association between the kinetic and electrophoretic properties of human purine-nucleoside-phosphorylase isozymes. Eur J Biochem 24:288-295

24. Spaapen LJM, Rijksen G, Staal GEJ, Zegers BJM 1983 Analysis of purine nucleoside phosphorylase from human $\mathrm{T}$ and non- $\mathrm{T}$ lymphocytes of different maturation stages. Clin Biochem 16:54-56

25. Fox I 1981 Metabolic basis for disorders of purine nucleotide degradation. Metabolism 30:616-634

26. Simmonds HA, Watson AR, Webster DR, Sahota A, Perrett D 1982 GTP depletion and other erythrocyte abnormalities in inherited PNP deficiency. Biochem Pharmacol 31:941-946

27. Spaapen LJM, Rijkers GT, Staal GEJ, Rijksen G, Wadman SK, Stoop JW, Zegers BJM 1984 The effect of deoxyguanosine on human lymphocyte function. I. Analysis of the interference with lymphocyte proliferation in vitro. J Immunol 132:2311-2317

28. Siegenbeek van Heukelom LH, Akkerman JWN, Staal GEJ, de Bruyn CHMM, Stoop JW, Zegers BJM, de Bree PK, Wadman SK 1977 A patient with purine nucleoside phosphorylase deficiency: enzymological and metabolic aspects. Clin Chim Acta 74:271-279

29. Jackson RC, Weber G, Morris HP 1975 IMP dehydrogenase, an enzyme linked with proliferation and malignancy. Nature (Lond) 256:331-333

30. Howard WJ, Kerson LA, Appel SH 1970 Synthesis de novo of purines in slices of rat brain and liver. $J$ Neurochem 17:121-127

31. Simmonds HA, Fairbanks LD, Morris GS, Timms P, Singh B, Bold A 1986 Erythrocyte GTP depletion in PNP deficiency presenting with haemolytic anaemia and hypouricaemia. In: Nyhan WL. Thompson LF, Watts RWE (eds) Purine and Pyrimidine Metabolism in Man, Vol V. Plenum Press, New York, pp 481-486

32. Hershfield MS 1981 Proposed explanation for S-adenosylhomocysteine hydrolase deficiency in purine nucleoside phosphorylase and hypoxanthine-gua nine phosphoribosyltransferase-deficient patients. J Clin Invest 67:696-701

33. Osborne WRA, Scott CR 1980 Purine nucleoside phosphorylase deficiency. Measurement of variant protein in four families with enzyme deficient members by an enzyme-linked immunosorbent assay. Am J Hum Genet 32:927-933 